\title{
LEGAL POLITICS OF WAQF-REGULATION IN INDONESIA
}

\author{
Havis Aravik \\ STEBIS IGM Palembang \\ Email: havis@stebisigm.ac.id \\ Nur Rohim Yunus \\ Universitas Islam Negeri Syarif Hidayatullah, Jakarta, \\ Email: nurrohimyunus@uinjkt.ac.id \\ Dwi Sulastyawati \\ Institut Agama Islam Negeri Curup Bengkulu \\ Email: dwisulastyati@iaincurup.ac.id
}

\begin{abstract}
The study investigates the government policies in the waqf's regulation in Indonesia and the essence of waqf as an important instrument of economic empowerment in Islam. The study aims to provide solutions to the lack of the benefits of waqf for people's welfare, especially in terms of economic empowerment. It is qualitative research with a normative approach. The research data used is the secondary data from library resources. An analysis of the data is by interpreting the concept. The result of this study shown that waqf has played a major role in citizen empowerment from the time of God's messenger, Muhamad peace be upon him until now, even the benefits of a waqf can still be felt up to today.
\end{abstract}

Keywords: waqf, political law, legislation.

\begin{abstract}
Studi ini membahas tentang kebijakan pemerintah dalam pengaturan secara legal formal wakaf di Indonesia, selain itu dibahas pula esensi wakaf sebagai instrumen penting pemberdayaan ekonomi umat dalam Islam. Kajian ini bertujuan memberikan solusi atas kurang berperannya manfaat wakaf dalam kehidupan masyarakat, terutama dalam aspek pemberdayaan ekonomi umat. Penelitian ini merupakan penelitian kualitatif dengan pendekatan normatif. Data penelitian yang digunakan adalah data sekunder berupa bahan pustaka. Analisis yang digunakan induksi-intepretasikonseptualisasi. Hasil penelitian ini menunjukkan bahwa wakaf sangat berperan penting dalam pemberdayaan masyarakat sejak dulu dari masa Rasulullah Saw sampai sekarang, bahkan manfaat wakaf masih bisa dirasakan hingga saat ini.
\end{abstract}

Kata Kunci: Wakaf, Politik Hukum, Peraturan Perundang-undangan

Nur El-Islam, Volume 6, Nomor 1, April 2019 


\section{A. Introduction}

Waqf is a charitable endowment and one of the important tenets of Islam. Historical facts show that waqf has played a major role in the development of various social, economic, educational, and cultural activities. Waqf used to be compared to zakat, concise, or alms. In facts, they have different characteristic. The waqf's existence has not yet been able to touch the essence of society's economy. This happens because studies on waqf have not been discussed intensively and comprehensively.

Consequently, Waqf had not been able to be managed and be maximized properly. Waqf downturns have not led to people's economic empowerment and it tends to be used only for religious and charitable purposes. ${ }^{1}$ Some of the causes are a limitation of human resources, especially on Nazir's side as an administrator and the lack of accountability of the waqf institutions. ${ }^{2}$

Based on the discussion above, knowing the nature of waqf as an important instrument of economic empowerment in Islam is so important to minimize the misunderstandings of waqf's function as one of the most fundamental components of people's empowerment, which its advantages almost ignorable.

\section{B. The Waqf institution in Islamic literature}

Waqf in Islam was well known as one of the key institutions that contributed greatly to social-economic development. ${ }^{3}$ Waqf was known in the second year of Hijri. It is the teaching Islam which has a social orientation and emphasizes on the importance of economic

1 Abu Azam Al-Hadi, “Upaya Pemberdayaan Tanah Wakaf Produktif Bagi Kesejahteraan Umat”Jurnal Islamica, Vol. 4, No. 1, September 2009, p. 97-98.

${ }^{2}$ A. Arif Budiman, “Akuntabilitas Pengelola Wakaf” Jurnal Walisongo, Volume 19, Number 1, May 2011, p. 75.

${ }^{3}$ Nathasa Mazna Ramli, Nurul Husna Mohd Salleh, dan Nurul Aini Muhamed, 2015. "Discharging Accountability Through Governance; Cases From Waqf Institutions in Indonesia”, Online Journal Research in Islamic Studies, Vol. 2, No. 1 (2015), p. 1. 
well-being and social welfare. ${ }^{4}$ In other sense, waqf is inclusive social worship. ${ }^{5}$

Waqf comes from the verb waqafa-yaqifu which means to be handled, guarded or restrained. ${ }^{6} \mathrm{Waqf}$ is also called al-habs and it's plural noun is al-ahbas, which means silence, inhibitions, obstacles. ${ }^{7}$ Generally, waqf was a kind of gift which is carried out in the way of. ${ }^{8}$ Wahbah Zuhaily declares that malikiyah defines waqf as the benefits of wakif's properties as rent or purse to those who are entitled to a certain within a certain period according to wakif's will. ${ }^{9}$ Waqf may also be understood as the giving of permanent property for religious social interests such as one who possesses a piece of land to be built on it a mosque or a public funeral. ${ }^{10}$

Waqf is one instrument in Islam that has a goal of increasing the community's welfare. continually. The role of waqf is vital, as waqf is voluntary properties for a public interest, to make is social responsibility in Islam. Waqf involves a permanent or temporary transfer from certain physical assets (mawquf) including cash from endower (waqif) to beneficiaries or administrators or guardians (mutawalli) through a legal instrument (waqfiyyah). ${ }^{11}$

${ }^{4}$ Fahmi Medias, “Wakaf Produktif dalam Perspektif Ekonomi Islam”, La Riba; Jurnal Ekonomi Islam, Volume IV, No. 1, July 2010, p. 69.

${ }^{5}$ A. Arif Budiman, “Akuntabilitas Pengelola Wakaf”, Walisongo, Volume 19, Number 1, May 2011, p. 76.

${ }^{6}$ Haslindar Ibrahim, Afizar Amir, Tajul Ariffin Masron, “Cash Waqf; an Innovative Instrument for Economic Development”, International Review of Social Sciences and Humanities, Vol. 6, No. 1 (2013), p. 2.

${ }^{7}$ Fakhry Zamzam dan Havis Aravik, Kamus Bisnis Syariah, Yogyakarta: Deepublish, 2016, p. 219.

${ }^{8}$ M. Nur Rianto Al-Arif, “Pemberdayaan Masyarakat Berbasis Wakaf Uang”, Jurnal Asy-Syir'ah, Vol. 44, No. II, 2010, p. 814.

${ }^{9}$ Wahbah Al-Zuhaily, Al-Fiqh al-Islamy wa Adillatuh, Beirut: Dar al-Fikr, 1981, p. $155-156$.

${ }^{10}$ Qurratul Uyun, “Zakat, Infaq, Shadaqah, dan Wakaf Sebagai Konfigurasi Filantropi Islam”, Islamuna, Volume 2, Number 2, December 2015, p. 222.

${ }^{11}$ Noorhayati Mansor, Amira Jamil, Asniati Bahari, “Integrated Waqf Reporting System”, International Journal of Accounting, Finance, and Business, Volume 2, Issues 6, December 2017, p. 156. 
Islam emphasizes that every activity of individual benefit other communities and get the blessing of almighty God. Muslims, therefore, should be able to spend some of their assets for the public, something that they value most, one of those ways is waqf (Qs. Ali Imran [3]: 92). ${ }^{12} \mathrm{~A}$ waqf in principle is the same as the infaq, but the difference is the eternity of its benefits, which is not to be sold and inherited. ${ }^{13}$ Waqf is the dedication of Muslims for the purpose of good faith which is recognized as generosity. ${ }^{14}$

From the discussion above, it is understandable that waqf is fully used for public purposes and is not allowed to perform any action on the property of waqf, except for profit. As their advantages are one way to attain maqhashid syariah. ${ }^{15}$ In addition, the essence of waqf laid in its advantages for the sake of peoples' welfare.

\section{The Urgency of the Waqf Economic Empowerment}

Islam views that poverty is entirely a structural problem, not a cultural problem. God has ensured that the sustenance of every creature has, is and will be created (Qs. Rum [30]: 40 and hud [11]: 6). At the same time, Islam is closing its doors to structural poverty by giving the obligation for each individual to seek income for their living (Qs. Al-mulk [67]: 15), individual sustenance is guaranteed (Qs. AlAnkabut [29]: 60) and will not be hungry (Qs. Thaha [20]: 18-19). Thus, from the Islamic perspective, poverty occurs because of human's error

${ }^{12}$ Nathasa Mazna Ramli; Nurul Husna Mohd Salleh; dan Nurul Aini Muhamed, 2015. "Discharging Accountability Through Governance; Cases From Waqf Institutions in Indonesia”, Online Journal Research in Islamic Studies, Vol. 2, No. 1 (2015), p. 2.

${ }^{13}$ Abdurrohman Kasdi, "Filantropi Islam Untuk Pemberdayaan Ekonomi Umat; Model Pemberdayaan Ziswaf di BMT Se-Kabupaten Demak”, Jurnal Iqtishadia, Vol. 9, No. 2, 2016, p. 230.

${ }^{14}$ Haslindar Ibrahim, Afizar Amir, Tajul Ariffin Masron, “Cash Waqf; An Innovative Instrument for Economic Development",Jurnal International Review of Social Sciences and Humanities, Vol. 6, No. 1 (2013), p. 2.

${ }^{15}$ Ahmad Mukri Aji, Urgensi Maslahat Mursalah Dalam Dialektika Pemikiran Hukum Islam, Bogor: Pustaka Pena Ilahi, 2012, p.55. 
in their economic behavior in the production, consumption, and distribution aspects. ${ }^{16}$

According to Amir Mahmud, there are five causes of poverty in society. Firstly, crimes against nature (Qs. Rum [30]: 41), humans being felt its effects (Qs. Asy-syura '[42]: 30). Secondly, the indifference and greediness of rich people (Qs. Ali Imran [3]: 180 and al-ma 'arij [70]: 18), leaving the poor trapped in the circle of poverty.

Thirdly, the presence of some men who are being greedy, exploiting and oppressing others is like eating the possessions of others vanity (Qs. At-taubah [9]: 34), consuming orphans's properties (Qs. An-Nisa '[4]: 2, 6, 10) and eating usury (Qs. Al-baqarah [2]: 275). Fourth, a concentration of political, bureaucratic, and economic power in one hand, as in the case of the Pharaoh, Haman, and Qarun (Qs. Alqashash [28]: 1-88). Fifth, an external factor, such as natural disasters (Qs. Saba [34]: 14-15), or wars that cause many evacuations (Qs. Alhasyr [59]: 8-9). ${ }^{17}$

Islam declared war on poverty and tried hard to contain it. Islam monitors the possibilities that could drive poverty to save the lives and morals of Muslims, preserve domestic life, and protect the stability and tranquillity of society. Islam has mentioned that one solution to poverty is waqf.

Along the course of Islamic history, waqf is proved to be one of the alternative institutions of philanthropy in solving national problems, like poverty and economic inequality. ${ }^{18}$ Waqf institutions, therefore, have a good potential to be part of a strong civil society, promotion of social-economic well-being in reducing the gap between rich and poor. ${ }^{19}$ Empowerment basically involves a bottom layer of

\footnotetext{
${ }^{16}$ Amir Machmud, Ekonomi Islam Untuk Dunia yang Lebih Baik, Jakarta: Salemba Empat, 2017, p. 222.

${ }^{17}$ Amir Machmud, Ekonomi Islam Untuk Dunia yang Lebih Baik, Jakarta: Salemba Empat, 2017, p. 223.

${ }^{18}$ Abdurrahman Kasdi, “Model Pemberdayaan Wakaf Produktif di Indonesia”,Jurnal Ziswaf, Vol. 1, No. 1, Juni 2014, p. 108.

${ }^{19}$ Nathasa Mazna Ramli; Nurul Husna Mohd Salleh; dan Nurul Aini Muhamed, 2015. "Discharging Accountability Through Governance; Cases From Waqf Institutions in Indonesia”, Online Journal Research in Islamic Studies, Vol. 2, No. 1 (2015), p. 2.
} 
poor society who is oppressed by the systems and social structures. Economic empowerment of the community could and have become a tool for the economic development of the people by maximizing the benefit of waqf. ${ }^{20}$

Economic empowerment of the community is all about activities aimed at improving the economy, for example; capital for entrepreneurship, education of economic skills, funds for consumption, and support for people in poor economic conditions, and so on. ${ }^{21}$ Waqf played a role to help the poor people, who are unable to strive for their lack of capital and for unemployed who are unable to be independent financially. ${ }^{22}$

Waqf is in line with modern economic objectives to be a better way to redistribute the income of society by delivering solutions to under-supply publics good. This is could be done by functioning a waqf for the benefit of the community. For example, using the waqf fund to provide fresh water, to support the creation of educational institutions, research, and libraries that will help to develop the quality of human resources. ${ }^{23}$

Waqf is also one form of public participation in improving the welfare of the people. With this participation, the burden on the state to alleviate poverty and to build economic prosperity is easier. The use of the waqf property for the economic empowerment o could be seen from the existence of waqf property used for educational, economic and social activities, as done by many Muslim countries such as Egypt, Turkey, Saudi Arabia, Jordan, Qatar, Malaysia, and many others. ${ }^{24}$

During the reign of Bosnia governor, Gazi husre-v-beg (14801541 C.E.) waqf was well maximized, enabled the economy of the

\footnotetext{
${ }^{20}$ Raihanah Daulay, "Pengembangan Usaha Mikro Untuk Pemberdayaan Ekonomi Umat Islam di Kota Medan”,Jurnal Miqot, Vol. XL, No. 1, January-june 2016, p. 46.

${ }^{21}$ Mohammad Nadzir, "Membangun Pemberdayaan Ekonomi di Pesantren”,Jurnal Economica, Volume VI, issue 1, May 2015, p. 40

${ }^{22}$ Rozalinda, Fikih Ekonomi Islam, Jakarta: PT. Raja Grafindo Persada, 2016, p. 321.

${ }^{23}$ Ruslan Abdul Ghafur, Konsep Distribusi dalam Ekonomi Islam dan Format Keadilan Ekonomi di Indonesia, Yogyakarta: Pustaka Pelajar, 2013, p. 113.

${ }^{24}$ Ruslan Abdul Ghafur, Konsep Distribusi dalam Ekonomi Islam dan Format Keadilan Ekonomi di Indonesia, Yogyakarta: Pustaka Pelajar, 2013, p. 113.
} 
people of Sarajevo. He built Sarajevo by using the very land he left behind. The use of the waqf was carried out for three purposes: firstly, building a mosque as a center of financial and state activities. The mosque is later known as the Gazi husrev-beg mosque which built around the 1530s; Secondly, building the school, public libraries, and facilities such as public toilets and bathrooms. The school then developed into one of Sarajevo's primary and intermediate centers, and the birth of Sarajevo University has continued until today. As for the library, it has the largest collection of Islamic manuscripts in the world; Thirdly, building the markets as a center of community economic activities, supplementing mosques and education centers. ${ }^{25}$

The use of waqf for public empowerment can be performed by improving the skills of the poor. Because wakif's treasures were not simply given to the poor, but how they could use the funds to be developed into many businesses as an aid to meet the daily needs of her daily life. This can be done in form of farming training, carpentry, management, business, services, and other institutions or the establishment in educational and training institutions, hospitals, micro-finance institutions, waqf Banks and others that are all aimed at improving the public's capacity to compete on the employment sectors and eradication of poverty. ${ }^{26}$

For these waqf instruments to be truly empowering the community's economy there are three main elements to be considered when choosing a small industry or community venture unit to be given the venture capital of the waqf fund: Firstly, it's a subsector of businesses that captures the lives and cultural traditions of some members of the community; Secondly, it is part of the work opportunities and the creativity improvement for labor forces that do not generally have no adequate formal education to enter the modern sector; Thirdly, it is a means of distributing opportunities for business and people income.

${ }^{25}$ Irfan Syauqi Beik dan Laily Dwi Arsyianti, Ekonomi Pembangunan Syariah, Jakarta: PT. Rajagrafindo Persada, 2016, p. 204.

${ }^{26}$ Ruslan Abdul Ghafur, Konsep Distribusi dalam Ekonomi Islam dan Format Keadilan Ekonomi di Indonesia, Yogyakarta: Pustaka Pelajar, 2013, p. 114. 
To exemplify, Institutions of education funded by waqf society are; the University of Al-Azhar in Cairo; Syanggit college in North Africa, Mauritania; Islamic Aligarh University, India, and Santi Niketan school. Egypt's Al-Azhar University in Cairo is known for waqf's wealth and the power of its base of funding, impolitically practical, is involved in education and proselytiousness, and remains independent and capable of safeguarding existence under any circumstance. Even Egypt's al-Azhar waken has cultivated Islam, both born and in nature. With a short time, al-Azhar could exist for no less than 1000 years, and he gave thousands of student's scholarships. AlAzhar has also built mosques and various dakwah institutions.

In the context of Indonesia, Irfan Sauqi Beik and Laily Dwi Arshianti study ${ }^{27}$ that the waqf lands cover approximately $4100 \mathrm{~km} 2$, which nearly six times of Singapore $(700 \mathrm{~km} 2)$. The value of waqf assets in Indonesia is 590 trillion, but the majority of these waqf assets are idle assets. This happens due to many factors: Firstly, lack of professionalism of waqf management. The waqf manager is not the owner of the waqf properties, but the manager or supervisor of the waqf properties, as Nazir only accepts the mandate from waqif. Nazir is obliged to do whatever is necessary and appropriate to protect and administer waqf properties; ${ }^{28}$ Secondly, there is a need to reform the Waqf management by implementing management principles based on the notion of waqf provisions, in general, giving space to make creations and creativities that bring benefit to the existence of waqf itself; ${ }^{29}$ Thirdly, it is necessary to reinterpret understanding of the waqf concept, especially for waqf managers, who is not only safeguarding

${ }^{27}$ Irfan Syauqi Beik dan Laily Dwi Arsyianti, 2016. Ekonomi Pembangunan Syariah, Jakarta: PT. Rajagrafindo Persada, 2016, p. 204.

${ }^{28}$ Achmad Arief Budiman, "Wakaf dalam Diskursus Fiqh Kontemporer Perspektif Majelis Tarjih Muhammadiyah”, Tajdida, Vol. 15, No. 2, December 2017, p. 28.

${ }^{29}$ Achmad Arief Budiman, "Wakaf dalam Diskursus Fiqh Kontemporer Perspektif Majelis Tarjih Muhammadiyah”, Tajdida, Vol. 15, No. 2, December 2017, p. 30. 
and doing routine matters but also looking for new innovations in order to develop and empower these waqf assets. ${ }^{30}$

Since the inception of act no. 41 in 2004 about waqf, with the basic goals of promoting the progress of waqf management in Indonesia. In this act, the waqf sector is expected to be able to function in a way that supports the socio-economic welfare of Muslims. ${ }^{31}$ The law includes neither moveable properties nor unmoveable properties, including a cash waqf which its use is so flexible. Such legal formulation clearly has a very revolutionary change, and if it is realized, it will have multiplier effects, especially in regard to Muslim empowerment. ${ }^{32}$

If the huge waqf potential could be maximized effectively, they could become a source of funds for development. The waqf was reliable for development in agriculture (farmland and agriculture), education (buildings and educational needs), health (hospitals and other health), and commerce (the management of the waqf land for trade centers). ${ }^{33}$ For that reason, Indonesia has to study with Bangladesh about waqf management through Social Investment Bank Limited (SIBL) which is able to raise funds from rich people to be managed and channeled to the people who are in needs. In fields of education, health and other social welfare through productive mechanisms in finding new funding in the form of a cash waqf certificate, which will be owned by the funder.

The waqf instrument is proof of Islam's concern for future generations. Islam requires that every generation always cares about the resources, and demand them to control its use for long-term interests. Every generation has continued to pay attention to the

\footnotetext{
${ }^{30}$ Abdul Hakim, “Manajemen Harta Wakaf Produktif dan Investasi dalam Sistem Ekonomi Syari'ah”, Riptek, Vol. 04, No. II, 2010, p. 22.

${ }^{31}$ Abdurrohman Kasdi, "Filantropi Islam Untuk Pemberdayaan Ekonomi Umat; Model Pemberdayaan Ziswaf di BMT Se-Kabupaten Demak”, Iqtishadia, Vol. 9, No. 2, 2016, p. 236-237.

${ }^{32}$ Fahmi Medias, “Wakaf Produktif dalam Perspektif Ekonomi Islam”,La Riba; Jurnal Ekonomi Islam, Volume IV, No. 1, July 2010, p. 70.

${ }^{33}$ Irfan Syauqi Beik dan Laily Dwi Arsyianti, Ekonomi Pembangunan Syariah, Jakarta: PT. Rajagrafindo Persada, 2016, p. 197-198.
} 
needs of future generations so that the current generation has to maintain and inherit waqf assets from generations to generations.

\section{Waqf Regulation in Indonesians' Legislation}

Indonesian's legislation basically has been passed since the Dutch colonization, and have continued until Indonesia's independent, through article ii of the constitution of 1945: "all the state's institutions and the regulations are applicable immediately, as long as nothing new is done, according to this constitution." For some adjustments to the independent state, there have been some guidelines for waqf, a guideline is from the ministry of religious affairs of the Republic of Indonesia on December 22, 1953. In this case, waqf is under the control of the social unit in this ministry. As a follow-up, on October 8, 1956, circular letter no $5 / \mathrm{d} / 1956$ has been issued. In 1960 the constitution of agrarian no. 51960 gave special attention to the waqf land, in chapter 49: 1) for services of worship and other sacred matters as referred in the article 14, it may be given waqf land owned by the state by the right to use. 2) owned land waqf are protected and regulated by government regulations.

Article 49 of the UUPA requires government regulation (PP) as a rule of its accomplishment. However, the government regulation remains unenacted government's seriousness for the waqf regulation is then questionable. It was not enacted until 17 years had passed, on May 17, 1977, the government issued government regulation no. 28 about waqf land along with a set of policies enacted by the ministry of religious affairs and the ministry of home affairs and several instructions from the regional governor. With this government regulation, all legislation on waqf asset, as long as it is on the contrary to these regulations, is no longer valid.

The waqf development is evidently increasing with the validation of compilation of Islamic law (KHI) through the president' instructions no. 1, 1991. In this KHI, the waqf received special attention in the book of iii. The content of the book iii consists of five chapters and 14 articles (215-228) which much of them are adopted 
from pp. no. 28 of 1977. Among those are the definitions of waqf that trusts in the duration of the item in an indefinite period (article 215).

In the end, there was a perspective for having a regulation on cash waqf that later becomes a stronger reason to conduct an update of waqf law. This wish came into the existence by the inception of waqf law 41 in 2004, along with PP. no. 42 in 2006 about the implementation of the waqf law. In contrast to the previous condition, at this time the climate of openness within the state governance was established. In fact, developed countries consider Indonesia as one of the democratic countries in the world. Not surprisingly, therefore, in the formation of a country's legal product, a state is responsive. It is proven that the government by means of the ministry of religious affairs took great care in the establishment of this law. Even more, the bill initiatives on waqf came from the state secretariat presented to the ministry of religious affairs when it proposed to the establishment of the Indonesian Waqf Board (BWI) ${ }^{34}$

Problems of waqf regulations have been resolved with the inception of waqf act No. 41 of 2004 and PP. No. 42, 2006. Whereas the problems associated with waqf fiqh have been responded to in some respects by the scholars, both by MUI and another Islamic civil society with their fatwa. Nevertheless, the clergy's response has not been able to resolve all waqf problems because of socialization and the dispute as a basic character of fiqh is still existed.

\section{E. The Direction of Law and Regulation of Waqf Land}

According to the political will of the state, as laid in law and regulation of waqf land, the government is not as executor of the waqf, but rather as regulators, motivators, facilitators, and public services for the waqf administration. In his duties, the state is assisted by the Indonesian Waqf Board (BWI).

${ }^{34}$ Djunaidi, Ahmad (et.al.), 2006, Proses Lahirnya Undang-undang No. 41 Tahun 2004 tentang Wakaf, Jakarta: Direktorat Pemberdayaan Wakaf Dertemen Agama RI, p. 120. 
With the inception of act No. 41 of 2004, the government (Department of religious affairs) made efforts to encourage and facilitate the management of waqf then it could be run securely and transparently. In order to achieve their goals. The ministry of religious affairs establishes waqf empowerment directorate under the domain of directorate general of Islamic civil society. With the birth of the directorate of waqf empowerment, which is apart from the Directorate of zakat empowerment, shows the serious attitude of the government in facilitating waqf better. With the waqf law enforcement in Indonesia, the waqf sectors have more functions in improving the social welfare of the people. It is clear from here that the social welfare interests are strongly influencing the process of regulation in the waqf properties regulation. The empowerment of waqf assets to be productive and professional is for the welfare of mankind in economic, educational, health, and other religious interests. ${ }^{35}$

This call prompted the creation of a cash waqf by investment companies, sharia Banks, and other Sharia investment institutions, it is also was done by the Tabung Wakaf Indonesia, Dompet dhuafa Republika, baitul mal muammalat and other institutions.

The explanation of waqf act no 41, 2004 state that the waqf properties are used not only for the benefits of public worship and social services but also to promote the public welfare by utilizing its economic benefits of waqf assets. This enables the management of the waqf's properties to run the economic activities in the broad sense, as long as the management of waqf and the economic principles are in accordance with sharia. The substance of the act number 41, 2004 on waqf, shows that the future of Indonesia's waqf is good enough and promising to solve society's social and economic problems.

Waqf is, basically, an "economic corporation," based on the future investment and developing a productive legacy for generations to come, as is the intended term, both in service and in the use of its

${ }^{35}$ Kadarismanto, "Rekonstruksi Wakaf Dalam Perspektif Hukum Berbasis Nilai Keadilan," dalam Jurnal Pembaharuan Hukum, Volume I No. 3 September - December 2014. p.333-335 
benefits. Kinds of waqf as presented are part of investment funds units. Investment is a major base for economic development. Investment means to make assets to become profitable in the future.

The investment intended by investors is to be able to produce a profit, which is economically planned and is channelled to beneficiaries (mauquf alaihi). Thus, it could be said that economically, waqf has built a productive treasure through investment activities for the benefit of beneficiaries.

The product of waqf thus could be distinguished into two parts: Firstly, direct waqf, namely waqf assets that produce public goods for direct consumption by people who are entitled to awqaf, such as hospitals, schools, orphanages, and settlements. Secondly, productive waqf, namely waqf managed for the purpose of investment and production of goods and services which are permissible under Islamic law. In this form, the capital of waqf assets is invested, and then the returns are distributed to those who are entitled.

In performing for the benefits of the people, we need a waqf reconstruction based on the value of justice. This was done to avoid the critical inequalities for the interests of worship and for the welfare of the people. As for the waqf reconstruction in act number 41 in 2004 are:

a. Article 22, act No. 412004 of waqf, the formulation is added as "waqf for the country's economic development capital, to be invested in profitable sectors;

b. Article 43, section (3), Act No. 41 of 2004 of waqf, the formulation is added as "the management of the waqf by nadzir is done productively and obligatory for profit";

c. Article 67, Act No. 41 of 2004 of Waqf, the formulation is added as "For anyone who intentionally abandons the Land of waqf, imprisoned for a maximum of 4 years and/or compensation of at least Rp. 500,000,000 (five hundred million rupiahs).

Reality shows that the existence of waqf asset could not be maximized, even though waqf is a potential Islamic economic social institution. If Indonesia's nazhir (waqf administrators) were willing and able to look into the management of the waqf by various countries 
Legal Politics of ...

such as Egypt, Bangladesh, and others, the profit of waqf management in Indonesia could be used to deal with current social and economic problems, such as poverty, unemployment, and other social problems. Especially waqf applied in Indonesia is not limited to things not only moveable and unmoveable assets, but also cash waqf.

\section{F. The Synchronization of Waqf Regulation with the Agrarian Constitution}

Waqf is a right on dominating land individually, within it are an authority, duty, and or ban for waqf landholders. The waqf land is a use of land for religious purposes, particularly for Muslim. UUPA take care of religious values in the use of land.

The evidence that UUPA heeds religious values can be found in: Firstly, the UUPA preamble under the letter a, in an opinion that due to such consideration, there is a need for national agrarian law based on the traditional land law, which is simple, and guarantees legal certainty for all of Indonesian, by not ignoring elements that rely on religious law; Secondly, the UUPA preamble under the words of the letter c, that the national agrarian law embodies the embodiment of belief in the one supreme God; justice and civilized humanity; the unity of Indonesia; the democracy led by understanding wisdom among honourable representatives from the parliament house; social justice for all people of Indonesia;

Thirdly, article 5. Agrarian laws that applied to the earth, water and space are traditional laws, so long as they do not contradict with the state and national interests, based on the unity of nations, with Indonesian socialism and its constitutions and other regulations. All things by considering the elements that are lied upon the fourth law of religion: article 14 section (1) By keeping the clause within it; article 2 section (2) and (3); article 9 section (2), article 10 section (1) and (2), in order to keep Indonesian socialism, created a general plan for supplies and the use of the earth's soil, for the water and space and the riches of nature within it: a. for the needs of the state; $b$. for the purposes of worship and other sacred needs, according to the believe in the one supreme God; c. for the need of human life, social, cultural, 
and other welfare; D. for the purposes of developing agriculture, livestock, fisheries and which are in line with them; E. for purposes of developing industries, transmigration and mining;

Fifthly, section 49: (1) Land rights owned by religious and social institutions which are used for religious and social enterprises are recognized and protected. These agencies are also assured of obtaining sufficient land for buildings and services in the religious and social sectors; (2) for the purposes of worship and other sacred matters as referred to in article 14, may be given land which is directly owned by the state by the right to use; (3) waqf properties with right of ownership are protected and regulated by the government regulations.

Waqf properties with right of ownership are set in article 49 section (3) UUPA, it is land owned waqf protected and governed by government regulations. This provision provided a special place for the use of land in regard to religious and social activities. In the explanation of article 49 section (3), UUPA states that to dispel the doubts and scepticism, this chapter gives a confirmation, that issues concerned with worship and other sacred needs, in the new agrarian law, will receive proper attention.

Article 49 section (3) UUPA commands further arrangements regarding government regulations on land owned waqf. The government ordinance is government regulation number 28 of 1977 on land waqf. Government ordinance number 28 of 1977 was enforced by the ministry of home affairs, regulation No. 6 in 1977 on a land registration for land owned waqf. The last legislation that regulates about waqf is set in 2004 on the waqf act.

An act No. 41 of 2004 was created with the intention of not to uproot or declare government regulation number 28 of 1977 is no longer valid. As such, land owned waqf is still in force by the government regulation number 28 of 1977 and the regulation of the ministry of home affairs number 6 of 1977. 


\section{G. Conclusion}

The conclusion of the above proposition may be concluded that waqf is a major institution on Islamic economic development. From the beginning, it gave great contributions to socio-economic development, so it is not surprising that it became an inclusive charity and social worship. Standing in line with zakat, infaq, and alms in the teachings of Islam. People's economic empowerment is a necessity, primarily with increased income gap between the rich and the poor. Waqf could be the solution to the problem of poverty, moreover, the early stages of Islam, waqf has been one of the pillars of Islamic economic power. Waqf is one form of public participation in increasing the well-being of the people. The use of waqf for the economic empowerment of community can be seen in the existence of that waqf for education, economic and social activities, as is practiced by many Muslim countries such as Egypt, Turkey, Saudi Arabia, Jordan, Qatar, Malaysia, and Indonesia. In Indonesia from the inception of act no. 41 in 2004 about waqf, waqf management has been restructured properly. The especially huge potential of waqf could be maximized for the source of development and welfare in Indonesia.

\section{References}

Aji, Ahmad Mukri. Urgensi Maslahat Mursalah Dalam Dialektika Pemikiran Hukum Islam, Bogor: Pustaka Pena Ilahi, 2012.

Al-Arif, M. Nur Rianto. "Pemberdayaan Masyarakat Berbasis Waqf Uang”, Jurnal Asy-Syir’ah, Vol. 44, No. II, Tahun 2010.

Al-Hadi, Abu Azam. “Upaya Pemberdayaan Tanah Waqf Produktif Bagi Kesejahteraan Umat”, Jurnal Islamica, Vol. 4, No. 1, September 2009.

Al-Zuhaily, Wahbah. Al-Fiqh al-Islamy wa Adillatuh, Beirut: Dar al-Fikr, 1981. 
Beik, Irfan Syauqi; dan Arsyianti, Laily Dwi. Ekonomi Pembangunan Syariah, Jakarta: PT. Rajagrafindo Persada, 2016.

Budiman, A. Arif. “Akuntabilitas Pengelola Waqf”, Jurnal Walisongo, Volume 19, Nomor 1, Mei 2011.

Budiman, A. Arif. “Waqf dalam Diskursus Fiqh Kontemporer Perspektif Majelis Tarjih Muhammadiyah", Jurnal Tajdid, Vol. 15, No. 2, Desember 2017.

Daulay, Raihanah. "Pengembangan Usaha Mikro Untuk Pemberdayaan Ekonomi Umat Islam di Kota Medan”, Jurnal Miqot, Vol. XL, No. 1, Januari-Juni 2016.

Ghafur, Ruslan Abdul. Konsep Distribusi dalam Ekonomi Islam dan Format Keadilan Ekonomi di Indonesia, Yogyakarta: Pustaka Pelajar, 2013.

Hakim, Abdul. "Manajemen Harta Waqf Produktif dan Investasi dalam Sistem Ekonomi Syari'ah”, Jurnal Riptek, Vol. 04, No. II, Tahun 2010.

Ibrahim, Haslindar; Amir, Afizar; Masron, Tajul Ariffin. "Cash Waqf; An Innovative Instrument for Economic Development", Jurnal International Review of Social Sciences and Humanities, Vol. 6, No. 1 (2013).

Kasdi, Abdurrahman. "Model Pemberdayaan Waqf Produktif di Indonesia”, Jurnal Ziswaf, Vol. 1, No. 1, juni 2014.

Kasdi, Abdurrahman. "Filantropi Islam Untuk Pemberdayaan Ekonomi Umat; Model Pemberdayaan Ziswaf di BMT Se-Kabupaten Demak", Jurnal Iqtishadia, Vol. 9, No. 2, 2016.

Machmud, Amir. Ekonomi Islam Untuk Dunia yang Lebih Baik, Jakarta: Salemba Empat, 2017.

Mansor, Noorhayati; Jamil, Amira; Bahari, Asniati. "Integrated Waqf Reporting System", International Journal of Accounting, Finance, and Business, Volume 2, Issues 6, December 2017. 
Medias, Fahmi. "Waqf Produktif dalam Perspektif Ekonomi Islam," La Riba; Jurnal Ekonomi Islam, Volume IV, No. 1, Juli 2010.

Nadzir, Mohammad. "Membangun Pemberdayaan Ekonomi di Pesantren”, Jurnal Economica, Volume VI, Edisi 1, Mei 2015.

Ramli, Nathasa Mazna; Salleh, Nurul Husna Mohd; dan Muhamed, Nurul Aini. "Discharging Accountability Through Governance; Cases from Waqf Institutions in Indonesia", Online Journal Research in Islamic Studies, Vol. 2, No. 1 (2015).

Rozalinda, 2016. Fikih Ekonomi Islam, Jakarta: PT. Raja Grafindo Persada, 2016.

Uyun, Qurratul, “Zakat, Infaq, Shadaqah, dan Waqf Sebagai Konfigurasi Filantropi Islam”, Jurnal Islamuna, Volume 2, Nomor 2, Desember 2015.

Zamzam, Fakhry; \& Aravik, Havis. Kamus Bisnis Syariah, Yogyakarta: Deepublish, 2016.

Zahrotunnimah, Zahrotunnimah; Yunus, Nur Rohim; Susilowati, Ida. "Rekonstruksi Teori Komunikasi Politik Dalam Membangun Persepsi Publik, "dalam Jurnal Staatsrecht: Indonesian Constitutional Law Journal, Volume 2, Nomor 2 (2018). 